RESIDENT

\& FELLOW

SECTION

Section Editor

Mitchell S.V. Elkind,

MD, MS

Michael D. Perloff, MD, $\mathrm{PhD}$

Andree M. LeRoy, MD

Erik R. Ensrud, MD

Address correspondence and reprint requests to Dr. Michael D. Perloff, Department of Neurology, Boston University School of Medicine, $72 \mathrm{E}$.

Concord St., C3, Boston, MA 02118

Michael.Perloff@nyumc.org

\title{
Teaching Video NeuroImages: The elusive L5 reflex
}

官

A 61-year-old man with a history of type 2 diabetes, obesity, and lower back pain had acute severe back pain with radiation down the right lateral-posterior thigh and across the anterior calf. MRI demonstrated severe right L5-S1 foraminal stenosis and EMG showed chronic right L5 reinnervation. The medial hamstring (semitendinosus and semimembranosus muscles) represents an L5 reflex. ${ }^{1,2}$ This reflex is difficult to elicit in supine or seated positions (video 1 on the Neurology ${ }^{\circledR}$ Web site at www.neurology.org), but is well-visualized with the patient prone (video
2). In this patient, the medial hamstring reflex was obvious on the left, but not the right. Patellar (L4) and ankle jerk (S1) reflexes were normal bilaterally, supporting an L5-specific lesion.

\section{REFERENCES}

1. Felsenthal G, Reischer MA. Asymmetric hamstring reflexes indicative of L5 radicular lesions. Arch Phys Med Rehabil 1982;63:377-378.

2. Jensen $\mathrm{OH}$. The medial hamstring reflex in the leveldiagnosis of a lumbar disc herniation. Clin Rheumatol 1987;6:570-574. 


\title{
Neurology
}

\author{
Teaching Video NeuroImages: The elusive L5 reflex \\ Michael D. Perloff, Andree M. LeRoy and Erik R. Ensrud \\ Neurology 2010;75; 50 \\ DOI 10.1212/WNL.0b013e3181f25ea6
}

This information is current as of September 13, 2010

\section{Updated Information \& \\ Services \\ Supplementary Material \\ References \\ Subspecialty Collections}

Permissions \& Licensing

Reprints including high resolution figures, can be found at:

http://n.neurology.org/content/75/11/e50.full

Supplementary material can be found at:

http://n.neurology.org/content/suppl/2010/09/12/75.11.e50.DC1

This article cites 2 articles, 0 of which you can access for free at: http://n.neurology.org/content/75/11/e50.full\#ref-list-1

This article, along with others on similar topics, appears in the following collection(s):

All clinical neurophysiology

http://n.neurology.org/cgi/collection/all_clinical_neurophysiology

All Education

http://n.neurology.org/cgi/collection/all_education

All Neuromuscular Disease

http://n.neurology.org/cgi/collection/all_neuromuscular_disease

Clinical neurology examination

http://n.neurology.org/cgi/collection/clinical_neurology_examination

Information about reproducing this article in parts (figures,tables) or in its entirety can be found online at:

http://www.neurology.org/about/about_the_journal\#permissions

Information about ordering reprints can be found online:

http://n.neurology.org/subscribers/advertise

Neurology ${ }^{\circledR}$ is the official journal of the American Academy of Neurology. Published continuously since 1951, it is now a weekly with 48 issues per year. Copyright. All rights reserved. Print ISSN: 0028-3878. Online ISSN: 1526-632X.

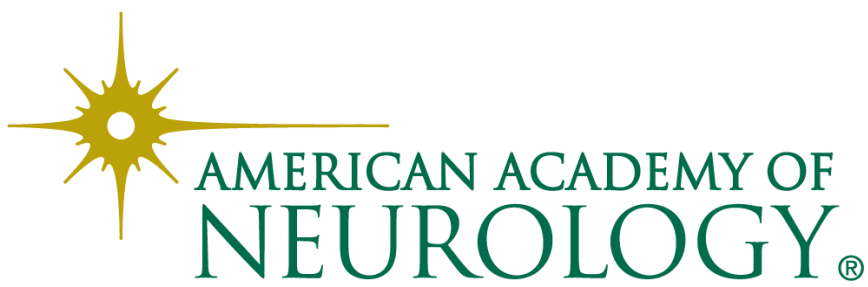

